\title{
RESUMO DE DISSERTAÇÃO
}

CARNEIRO, Bárbara Luisa Ferreira. Análise das competências em informação dos idosos no uso das tecnologias digitais. 2018. 119 f. Dissertação (Mestrado em Ciência da Informação) - Programa de PósGraduação em Ciência da Informaç̧ão, Universidade Federal do Ceará, Fortaleza, 2018.

\section{ANÁLISE DAS COMPETÊNCIAS EM INFORMAÇÃO DOS IDOSOS NO USO DAS TECNOLOGIAS DIGITAIS}

\author{
THE ANALYSIS ON INFORMATION LITERACY OF ELDERLY AT USING DIGITAL \\ TECHNOLOGIES
}

\section{RESUMO}

Esta pesquisa tem como objetivo analisar as competências em informação dos idosos no uso de tecnologias digitais. Para tal, adota como objetivos específicos: a) identificar as necessidades informacionais dos idosos; b) verificar como os idosos utilizam variados recursos e fontes informacionais no âmbito digital; e, c) examinar os aspectos cognitivos, situacionais e afetivos relacionados, respectivamente, ao saber, ao saber-fazer e ao saber-agir da competência em informação. Tem como pressuposto o fato de que a competência em informação supera abordagens preocupadas apenas com as habilidades voltadas à solução de problemas em atividades formais, constituindo-se em fator crítico para a realização de outras atividades, as quais ressaltam diferentes naturezas da informação. Quanto aos procedimentos metodológicos, a pesquisa se ampara na abordagem qualitativa e no método exploratório e descritivo. Para a coleta de dados, privilegia a interação face a face através da realização de entrevistas com idosos que utilizam tecnologias digitais. A técnica utilizada para a interpretação dos dados foi a análise de conteúdo. Por meio do mapeamento das competências informacionais, destaca que os idosos entrevistados, em sua maioria, demonstram interesse em continuar a aprender sobre as tecnologias digitais e suas ferramentas. Os resultados da pesquisa apontam que, apesar das dificuldades encontradas, os respondentes têm curiosidade em conhecer os avanços tecnológicos e alimentam o desejo de aprender cada vez mais sobre as ferramentas disponíveis. Ainda que, por vezes, os idosos apresentem certo receio e resistência ao novo, vale destacar que, em muitos outros momentos, há um sentimento de motivação e interesse pelo aprendizado, sempre com vistas à conquista de independência em tarefas associadas à tecnologia. Desse modo, conclui que a utilização das tecnologias digitais pode proporcionar uma maior autonomia dos idosos, contribuindo positivamente com sua qualidade de vida, além de cooperar com outras pesquisas sobre o desenvolvimento da competência em informação em contextos digitais.

Palavras-chave: Competência em Informação. Necessidade Informacional. Tecnologias digitais. Velhice. Terceira Idade.

\section{ABSTRACT}

This research aims to analyze the information literacy of the elderly in use of digital technologies. Therefore, it adopts as specific objectives: a) identify the informational needs of the elderly; b) 
verify how the elderly use diverse technological resources and informational sources in the digital space; and, c) examine the cognitive, situational and affective aspects related, respectively, to knowledge, to know-how and to know-agency of information literacy. Part of the assumption that the information literacy surpasses approaches preoccupied only with the problem-solving skills in formal activities, constituting a critical factor for the accomplishment of other activities, which emphasize different natures of information. As for the methodological procedures, the research is based on the qualitative approach and on the exploratory and descriptive method. For data collection, it favors face-to-face interaction by conducting interviews with elderly using digital technologies. The technique used for data interpretation was content analysis. Through the mapping of information literacy, it is highlighted that the elderly interviewed, for the most part, show interest in continuing to learn about digital technologies and their tools. The results of the research indicate that, despite the difficulties encountered, respondents are curious about technological advances and encourage the desire to learn more about the available tools. Although the elderly sometimes present some fear and resistance to the new, it is worth noting that in many other moments there is a sense of motivation and interest in learning, always with a view to achieving independence in tasks associated with technology. In this way, it concludes that the use of digital technologies can provide greater autonomy for the elderly, contributing positively to their quality of life, and cooperate with other researches on the development of information literacy in digital contexts.

Keywords: Information literacy. Information needs. Digital technologies. Old age. Third Age.

\section{SOBRE O AUTOR}

Bárbara Luisa Ferreira Carneiro

Mestra em Ciência da Informação pela Universidade Federal do Ceará (UFC).

E-mail: barbaracarneiro@hotmail.com

Recebido em: 31/10/2018; Aceito em: 09/11/2018; Revisado em: 10/12/2018.

Como citar este resumo:

CARNEIRO, Bárbara Luisa Ferreira. Análise das competências em informação dos idosos no uso das tecnologias digitais. Informação em Pauta, Fortaleza, v. 3, n. 2, p. 137-138, jul./dez. 2018. Resumo de Dissertação. DOI: https://doi.org/10.32810/2525-3468.ip.v3i2.2018.39519.137-138. 